\title{
AC 2009-2208: BRINGING PROFESSIONAL EXPERIENCE INTO THE CLASSROOM: FACULTY EXPERIENCES
}

\section{Karen Chou, Minnesota State University, Mankato}

Karen C. Chou is Professor of Civil Engineering and former Civil Engineering Coordinator at Minnesota State University, Mankato. Dr. Chou has over 25 years of professional experience and is a registered P.E. in New York, Tennessee, Minnesota, Wisconsin, Iowa, and South Dakota.

\section{Deborah Nykanen, Minnesota State University, Mankato}

Deborah K. Nykanen is an Associate Professor of Civil Engineering at Minnesota State University, Mankato. Her teaching, research and professional experience focus on water resources, hydrology and hydrometeorology. Dr. Nykanen has 8 years of academic experience and is a registered P.E. in Minnesota. 


\title{
Bringing Professional Experience into the Classroom - Faculty Experiences
}

\begin{abstract}
For over two decades, ASCE has been advocating bringing faculty members to the work place to gain professional experience so that he/she could incorporate the experience into the classroom. While this is a wonderful concept, very few faculty members especially the young, non-tenured ones have taken advantage of the opportunity. The primary obstacle was believed to be the "publish or perish" criterion for tenure and promotion. This is especially true for those research focused institutions. Today, "publish or perish" is still believed to be the obstacle for the lack of faculty members working in the professional field while holding a full time faculty appointment.

The first author was a young faculty member two decades ago who used that exact reason for not seeking a summer engineering position while holding a faculty position. Two years ago, the first author had an opportunity to join a local architect firm as a part time structural engineer. The experience both personally and professionally is well beyond expectation. The second author also had an opportunity to work with a civil engineering firm during one summer. Her experience was significantly different from the first author. In this paper, the authors will summarize the benefits of their experience which have been used to enhance students' learning, from the freshmen introduction to civil engineering class to the senior capstone design project. In addition, the authors will offer their perspective as a faculty-engineer and the factors influencing the effectiveness of this "dual" position. "Publish and perish" is not the only reason why so few faculty members are interested in this "dual" position. The support from engineering professionals is also very important. The owners of the firms must have genuine interest in having the faculty member incorporate his/her professional experience into the classroom to enhance student learning. They also need to be supportive of the faculty member and, in particular, be willing to accommodate a flexible work schedule.
\end{abstract}

\section{Introduction}

It is well known that engineers apply mathematics and engineering principles and concepts to solve problems. Traditionally, the theoretical concepts are taught in the classroom while the applications of the theory, in particular the practical applications, are mostly acquired on the job. Unfortunately, this segregated dissemination of knowledge from the faculty and experienced engineers creates a gap that the engineering graduates must try to bridge upon entering the engineering profession.

The need to expose students to "real world" engineering practice during their academic learning process is embraced by students ${ }^{1,2}$, faculty, and the engineering profession. Efforts have been made over the past few decades in an attempt to provide the real world engineering experience to the students. Among them are internships ${ }^{3,4}$, co-op programs ${ }^{3}$, real-world based case studies and design projects $^{5-10}$, a total re-design of the capstone design course ${ }^{11-12}$ under the current ABET accreditation criteria, bringing engineers to the classrooms as guest speakers, and having engineers as adjunct faculty. Each of these approaches yields various levels of success. Other 
suggestions, which have been more difficult to implement, include asking full time faculty members to work in an engineering firm during the summer, having faculty members spend their sabbatical leaves in an engineering firm, and having full time engineers spend a year of paid leave in a university. There also exist situations where companies send engineers to the classroom at the expense of the companies and situations where engineers with many years of practicing experience decide to have a second career in academia. Students in primarily engineering technology programs indicated that as a result of including real world engineering experiences in the curriculum they became more job ready and were actually receiving job offers

as a result. ${ }^{13,14}$ More recently and partly in response to ASCE's Body of Knowledge ${ }^{15}$ report and Policy $463^{16}$, many schools such as Tufts University and Lehigh University created a "professor of practice" or similar position to bring engineering practice to the classrooms. The success of this approach has not yet been assessed formally.

In this paper, the focus is on having faculty members acquire the engineering practice through summer or part time employment with an engineering firm so that real world engineering experience can be shared with the faculty member's students. The authors recognize this is not a new concept. However, through their personal experience, they discovered that the value of this approach is not obvious and "publish or perish" is not the only factor influencing the effectiveness of this concept. In the following sections, the authors will share with the engineering community, both academia and industry, the experience they had with their respective second job at an architectural firm and a civil engineering firm and the factors they believe need be addressed to make this concept effective.

\section{Background}

In the 1950's the engineering students were taught by professors whom a majority of them were engaging in engineering practice. These faculty members either worked as private consultants or worked with an engineering firm. The highest degree these faculty members possessed may have only been a master of science or master of engineering. As the focus of fundamental research heightened and the availability of research funding increased during the early 1960's, many engineering professors directed their interest towards research instead of engineering practice. At the same time the universities' demand on scholarly work from their faculty members started to increase and continues to now. The term scholarly work generally required a professor to acquire research funding, conduct research, supervise graduate students, and publish papers. The faculty hired in that era typically possessed a Ph.D. degree with the exception of a small minority who went to predominately undergraduate schools. Under the pressure of "publish or perish", the new faculty of this generation focused their energy in scholarly work. Despite the desire of a faculty member to incorporate practical applications in the classroom, the goal was rarely achievable due to the faculty members' lack of time and the typical lack of a university's recognition and reward system in acquiring practical engineering experience.

The call for increasing engineering practice experience in the classroom came at least as early as the 1980's from the engineering profession and the American Society of Civil Engineers (ASCE). While there is a desire to achieve this goal, the means to accomplish it are not well defined. Using engineers as adjunct faculty has been one of the most popular ways to achieve this goal. However, the success of this arrangement in meeting the goal is unknown. 
Based on the authors' observations of many programs that have utilized this approach, the success depends on the host program's interaction with the adjunct faculty and the adjunct faculty's understanding of the academic mission. The host program must communicate with the adjunct faculty the difference between academic learning and practice. For example, it is necessary for the adjunct faculty to understand the importance and need for the students to understand the derivation of an equation and not just the rule of thumb design value. The adjunct faculty also must understand the need for the students to understand the concepts that are being used in other areas such as bridges and power plants instead of only buildings or structures that the adjunct faculty is experienced with. Furthermore, when the authors' program hired a city engineer to teach a course for them, he was shocked to learn that he exhausted a day's preparation within the first hour of a 2-hour lecture on the first day of class. If the department faculty interact regularly with the adjunct faculty and essentially serve as teaching mentors to the adjunct faculty, especially during the first few teaching assignments, the effectiveness of the adjunct faculty would increase significantly. However, since the teaching schedule of adjunct faculty is typically in the late afternoon or evening, the interaction between a teaching mentor and the adjunct faculty is very limited.

The availability of the adjunct faculty outside the classroom is another factor. Students' learning occurs not just in the classrooms, but also comes from interaction outside the classrooms. Due to the adjunct faculty's commitment in his/her engineering position, his/her availability is usually limited to before or after class. Even with the convenience of internet and mobile phones, the informal interaction between the students and the adjunct faculty is still limited to course related questions rather than profession related discussions. Despite the potential obstacles discussed, having engineers as adjunct faculty is still the most widely used method in bringing engineering experience to the classrooms.

The first author was an engineering student during the mid-1970's. At the time, her alma mater was a teaching focus school where about half of her professors in civil engineering possessed only masters degree. The non-Ph.D. faculty members either worked part-time in an engineering firm or full-time during the summer or both. She pursued her post graduate education at a research focused university. During her Ph.D. studies, she had a geotechnical engineering professor who had extensive consulting experience in foundation design. For each foundation type the professor lectured on, he would discuss issues raised during the design and construction that he encountered from his consulting experience. While the first author recognized the benefit of learning from professors with vast practical experience, this realization was amplified as she became a faculty member herself in the early 1980's. Although the author had worked briefly (about $1-1 / 2$ years) as a structural engineer in a fairly large engineering firm specialized in hydropower projects, the author still felt inadequate when attempting to relate the engineering concepts to engineering practice. Her work was focused on finite element analysis of various sections of a dam. As a junior faculty in a research oriented university, the first author felt the pressure of "publish or perish". Early in her career, she was contacted by ASCE regarding opportunities available for faculty members like herself to engage in practical engineering experience in the summer. The caller also indicated the lack of interest among faculty members in this opportunity. The first author offered her dilemma of "publish or perish" as the most probable reason for the lack of interest. 
The second author completed her undergraduate and graduate education in the 1990's at a research focused university. With the exception of a project management course, the real world experience brought into the classroom during her education was very limited. She worked parttime at a consulting engineering firm throughout her undergraduate education, and gained some practical experience through the mentoring provided by her employer. During graduate school she worked on research in hydrometeorology and gained a strong background in theoretical water resources engineering. After completing her Ph.D., she accepted a tenure-track faculty position at a university that was a mix of professors focused on research $(\sim 75 \%)$ versus those focused primarily on teaching $(\sim 25 \%)$. At times, this mix created disharmony in the department due to differing teaching loads and priorities amongst the faculty. The teaching focused faculty members had been at the university for a good portion of their career and were long since tenured. The "publish or perish" motto had swept through the university within the past decade and it was obvious that there were high research expectations of new tenure-track faculty. However, in her discussions with students, it was clear that they valued and benefited from the real world applications that were more commonly brought into the classroom by the teaching focused faculty. In teaching her classes, she felt solid on the theoretical aspects of what she was teaching but always felt ill-equipped to answer practical application questions raised by curious students. Her research program was ramping up with two federal grants and there was simply no time to even consider getting real world experience. And since the tenure process did not allow for value to be placed on gaining practical experience, there was no motivation or incentive to purse professional experience opportunities. After 2-1/2 years she made a career decision based solely on family reasons and accepted a tenure-track faculty position at a teaching focused university located closer to her extended family. Here, she was encouraged to obtain her professional engineers (P.E.) license and was encouraged by the program coordinator to bring practical experience into the classroom.

The interest of having faculty possessing practical experience in addition to being a good teacher and a good scholar (publish or perish) has increased in the past decade. Evidence of this can be found in the advertised announcement of most faculty position openings in the past couple years. With the evolution of ABET accreditation to the current criteria, the importance for students to be exposed to or gain practical experience during their academic careers has gained more prominence. The desire to have faculty with practical experience as well as corresponding research capability has increased. The demand from the engineering profession that new graduates should have an understanding of the engineering practice has also increased. Most companies consider graduates with internship experience as an added value ${ }^{3}$. Still, the need for the students to be exposed to engineering practice in the classrooms has not diminished ${ }^{1}$.

The authors had a unique opportunity to be part of a brand new civil engineering program in a fairly small city. The next big city is about 75 miles away. Before a single civil engineering student was accepted to the program, an industry advisory board was formed. Part of the advisory board's mission is to provide internship opportunities for faculty in addition to providing engineering practice support to the program such as guest lectures, participation in senior capstone design, etc. The authors took advantage of this opportunity and worked with firms near the university campus. 


\section{Faculty Engineering Practice Experience}

The first author is a structural engineer. Since the summer of 2006, she has worked as a part time structural engineer with an architectural firm. The second author is a water resources engineer. In the summer of 2007, she worked for a consulting engineering firm specialized in civil, environmental and transportation engineering, and land surveying. The firm also serves as the city engineer for many small communities in the surrounding area. The experience both of the faculty members gained from their respective engineering jobs is vastly different. Following is a brief summary of their job experience.

\section{Structural Engineering Faculty's Experience}

As a part time structural engineer, she worked with a full time structural engineer-in-training. Their function was to support all the structural engineering work of the architectural firm. The projects varied from simple foundation design for pre-design engineering buildings to multimillion dollar LEED certified judicial building and almost everything in between such as churches, elementary schools, college buildings, and medical, financial, commercial, and residential facilities. Most of the buildings are one to two stories. Building types include wood frames, masonry, steel frame, and prestressed concrete. As engineer-of-record, she reviewed all structural designs. She also worked on different phases of the design process. This included working with architect designers during design development phase where grid lines were established and building frame was determined. The majority of her work was done during the construction development phase. In this phase, she did a variety of structural element designs such as foundations, retaining walls, beams, columns, shear walls, bracing and detail design such as connections, lintels, and headers. In addition to sizing the structural members, she also worked with mechanical and electrical engineers to make sure the structural members can support the mechanical equipment and not interfering with the electrical conduits. Once construction was underway, she observed the construction periodically. The experience gained in this phase is immense. She did not just walk around the construction site, but was also able to participate in some construction meetings and address contractor's concerns when they arose. Most important of all, unexpected conditions were occasionally encountered during the construction phase which required modification of the design. For example, in one project, the bottom elevation of the wall foundation was different from the bottom elevation of a spread footing that was located near the wall foundation. Due to the close proximity of these two foundations and the difference in bottom elevation, it could create a potential problem during the soil compaction stage. It was during one of the site observations that the engineer realized a potential problem could occur and proposed a "fix" for the situation.

\section{$\underline{\text { Implementation of Professional Experience in Classes }}$}

Since the structural faculty member's association with the architectural firm, the first author was able to take her students on a number of field trips during the appropriate stage of construction as she was kept abreast of the construction schedule of all the projects the architectural firm worked on. In one project, she was able to schedule a field trip to a concrete production plant to see the manufacturing of double-tee floor beams and architectural concrete wall panels. In the following week, they visited the construction site where these products were being erected. Prior to the 
field trips, the first author was able to provide a brief presentation on the design of the building and the unique features that the students should observe during the site observation.

During one of the senior capstone design projects, the first author directed the students to an architect-designer in her firm to discuss issues such as the American Disability Act, clearance for hallways, classroom sizes, etc. that needed to be followed in the academic building being designed by the student structural group for their project. Furthermore, these students also met with the full-time engineer intern in the firm to discuss a beam layout that could yield a more economical building because of the shallower steel beam depth. The class also was asked to attend a construction meeting as observers.

The first author was able to assign design problems or discuss design issues with the class based on the projects she worked on. In the reinforced concrete design class, she assigned a combined footing design to the students. The design information was based on a project she had just completed. The circumstances surrounding the need of a combined footing, instead of a spread footing, were discussed. The primary reason was that the engineer of the existing building did not design the footings to accommodate the expansion which was known at the time. The combined footing was determined to be the most economical solution. Another example was on steel column design. The AISC Steel Manual of Construction ${ }^{17}$ contains tables showing capacities of various column shapes and lengths. Yet, the students must understand the need for them to understand the design concepts and all the associated calculations. The situation the first author used from one of her projects was that after a building was framed and roofing was scheduled, it was discovered that a corridor clearance was not met and two columns required modifications. Due to the construction schedule, and the cost of delays, it was decided that these columns be "shaved" on-site. The engineer had to calculate the capacity of the modified columns manually.

Because of the first author's exposure and involvement in many projects with the architectural firm, she was able to capture images from these projects at various construction stages. These images were incorporated into various courses such as introduction to engineering in the freshman year, structural analysis in the junior year, and steel and reinforced concrete design in the junior/senior year. Furthermore, these projects were all within 30 miles of campus. Most students recognized the structures which made discussion of the projects more interesting and relevant and helped motivated them to ask questions in class. ${ }^{2}$

\section{Water Resources Faculty's Experience}

The water resources faculty worked part-time in a civil engineering firm during the summer of 2007. Her experience was significantly different from that of the structural faculty member. She was assigned to one of the largest water resources projects the firm had secured to date, a comprehensive storm water management plan for a suburban city. She was one of several engineers working on the storm water model, which included delineation of urban drainage areas and mapping out the location, elevations and sizes of existing catch basins, storm water pipes and detention ponds throughout the city. The project consumed the majority of her summer work time at the firm. She learned some practical applications within the first couple weeks on 
the project, but then it quickly became repetitive work with no added value for the purposes of broadening her real world experience.

Towards the end of her summer job, she worked on a small culvert design project for one week. It was refreshing to switch projects and gain some different experience. Although the consulting engineering firm needed the extra help on the large project which was still in progress, they began to realize that having the faculty member spending almost the entire summer on one project was not beneficial to her goal of gaining diverse experience in engineering practice. However, the change came too late in the summer with only one week left. The faculty member did not have the opportunity to see a variety of projects in the water resources area or to visit any sites in the field.

\section{$\underline{\text { Implementation of Professional Experience in Classes }}$}

Prior to the summer of 2007, the water resources faculty was teaching the junior-level hydraulics and hydrology course for the sixth time. She felt she was starting to reach a plateau on how to continue improving the course. Gaining some real world experience was necessary to bring her teaching up above that plateau. Based on her summer professional experience, she was able to make several improvements to the course in subsequent semesters. It gave her the confidence that she was covering the foundational material necessary to prepare students for a career in water resources engineering. The large project that she worked on for the majority of the summer provided her with knowledge on modeling techniques, rules of thumb and common practice in stormwater management. She was able to express to-the students how important it is that they understand the different options and calculations being performed in a model rather than treating it as a "black box". She was able to share her experience from the water resources project she worked on with the class while covering the theoretical aspects of sizing storm pipes and designing detention ponds. The importance of testing the sensitivity of model results to rule of thumb values used was also discussed. For example, engineers commonly assume a Manning's roughness value of 0.013 for concrete pipes. However, it is important to consider how this value may deviate from the rule of thumb (e.g., aging pipes) and explore the effect on the overall system performance.

The one week of her summer that the water resources faculty was able to work on a culvert design for a railroad bridge crossing provided her with several improvements to her junior-level hydraulics and hydrology course and also to a senior-level open channel flow elective course. The United States Geological Survey (USGS) regression equations were used for estimating peak flow for this ungaged basin. This technique is often not covered in hydrology textbooks. Therefore, she had not previously covered this method in her class. Following her summer experience, she added the USGS regression equation peak flow method to her course and was able to share her experience from the culvert design using this method with the class. The other valuable experience that she gained on this short project was a reminder to consider alternative paths that surface runoff and open channel flow in natural channels may take. After careful review of the topography of the drainage area and streambed, it was determined that the bulk of the water would not follow the path that was originally assumed by the engineers. Without this careful review, the culvert would have been placed at the wrong location. Through the faculty 
member's involvement in this process, she was able to share this experience with the senior-level open channel flow class.

\section{Assessments}

\section{Students' Perspective}

Both authors had prior experience of teaching at research focused universities. It is quite clear that the students at the current institution are more vocal on their desire to have faculty members who have practical experience. Almost all of the students have summer engineering internship experience. Many chose civil engineering because they held construction or civil engineering technician positions before returning to school. Although neither author conducted a formal survey from the students on the benefit of having the authors working during the summer or part time, there were student comments, both verbally and written on course evaluations, directly focused on their professional experience. Following are some selected comments.

The senior class of 2007 - during the individual interview with the students on the design project, one student commented the advantage that the structural group had on having consultation and guidance from someone with practical experience. This structural group was the one the first author sent to meet with the engineer intern and the architect-designer of the architectural firm she works with.

The reinforced concrete design class - students wrote on the course evaluation specifically on the combined footing problem that the first author assigned to them. They felt that they were doing real design work.

The hydraulics and hydrology class - in previous semesters, the second author routinely received a comment on course evaluations from one or two students mentioning her lack of professional experience. However, she has not received any similar comments on course evaluations since the summer of her professional experience.

At the beginning of each semester, the first author gives a brief introduction of herself to the class. The reception from students was extremely positive when they learned of her engineering experience. There was also a significant increase in student inquiries on projects that were under construction in the city where the university is located.

The second author experienced an obvious increase in student interest in topics when she shared real world experience that she gained during her summer working at the consulting engineering firm. Students that seemed to be losing focus during the class period were re-engaged in the material. Essentially, the students' ears would perk up whenever she discussed real world experience and applications. This has motivated her to continually incorporate visual aids, examples and projects into the class that are real world applications.

\section{Faculty's perspective}

The first author was fortunate to have the opportunity to work on a variety of projects during the past two and a half years. Some of the benefits from the students' perspective were presented in the previous section. Unlike the experience she had with the hydropower projects over 25 years 
ago, almost all of the projects she worked on with the architectural firm were completed within the past two and a half years. In addition, the types of projects were so diverse that she could draw on many examples from her experience and use them in various classes. Professionally, the first author felt that she is a better instructor because of the professional experience she acquired despite that she already had over 20 years of teaching and research experience.

The second author cites the confidence that she gained in knowing that she was covering the fundamental material necessary to prepare students for a career in water resources engineering as the most beneficial outcome of her summer practical experience. Being able to observe that the engineers in the consulting firm use the equations and concepts in practice that she covers in class and that the models they use are based on the theory she covers was encouraging and it motivated her on the importance of her role as an educator.

Reflecting back on her summer experience, the second author realizes the importance of discussing more explicitly at the start of employment her goals of gaining diverse practical experience and field site exposure during the summer job. With the looming deadlines of a large project, it was too easy for these goals to get lost and the firm to view the faculty member as an extra hand to drudge through necessary repetitive work. It is important for the faculty member and engineering firm to have a clear understanding at the start of employment on the purposes of the summer experience and to work together to make sure these goals are met.

\section{Factors That Influence the Experience}

It is clear that the two faculty members had different engineering experience from their respective part time positions. Based on their experience, they would like to offer the following observations.

- Both firms were extremely supportive of the faculty members' desire to gain engineering experience and were proud to be able to provide them with the opportunity. However, the faculty members were unsure if the firms fully understood the means to provide them with the experiences that they could also use in the classroom during the short employment period.

- In order for the faculty member to gain the most during the short summer months, they need to work on as many different projects as possible. These projects should reflect different engineering applications in the faculty member's discipline. In some cases, the faculty member's contribution to a project could be very minimal or simply as an observer.

- Sometimes, it is not necessary for the faculty member to see the projects from the beginning to the end. If the faculty member participates in different stages of a project and participates in enough projects, collectively, he/she should have an understanding of how a project is initiated, planned, designed, and executed that would generate fruitful discussions in class.

- It is more beneficial for a faculty member to have a part-time, year-long appointment with a firm than just summer employment. For the faculty member to have the opportunity to work on various phases of a project and to see a variety of different projects, it is better to have a long term association with the firm. However, recognizing the faculty member's schedule during the academic year, the firm must be willing to give the faculty member a flexible schedule. 
- Opportunity to work in a smaller firm with more and diverse project types may be more beneficial to the faculty members and their students than a large firm with large and more focused projects.

\section{Concluding Remarks}

Having engineers as adjunct faculty has been a common way of bridging the gap of theory and practice in the academic arena. While this arrangement appears to be beneficial to the students, its value has never been assessed formally. ASCE advocated an alternative approach of bringing faculty to the work place to gain engineering experience. It was expected that the faculty would then be able to incorporate the experience into the classroom. This arrangement was not as well received as the adjunct faculty arrangement. The common belief was that the faculty, especially the junior ones, would not wish to risk their tenure and promotion under the "publish or perish" evaluation criteria in academia.

In this paper, two faculty members from one university decided to work in their respective fields with an architectural firm as a part time structural engineer and with a civil consulting firm as a part time water resources engineer during a summer. Their engineering experience and ways to incorporate their experience to enhance students' learning were presented. It is obvious that the biggest contrast between these faculty members' engineering experience is the diversity of projects and involvement by the faculty member. Based on the authors' experience, they offer the following suggestions.

- The firms should understand the mission and goals of the faculty working part time or during the summer. The faculty member needs exposure to a diverse set of projects within their discipline.

- If possible, the faculty member should seek a part time appointment with a firm throughout the year rather than just a summer appointment.

- The firms need to be very flexible with the faculty member's schedule during the academic year. In addition, the university needs to not only be accommodating but also place value on the engineering experience gained by the faculty member through this arrangement.

- It is important for the engineering firms to realize that to help faculty members gain the widest exposure to engineering practice, some of their hours may not be billable to the client such as going to a construction observation or attending a meeting with a client where the faculty member is merely an observer and not a member of the project team. The firms should partly consider the employment opportunity for the faculty as a service to the university and an investment in the quality of future graduates.

- Faculty interested in a dual faculty-engineer career should consider working for firms with smaller and diverse project types.

Although the authors did not discuss the faculty member's contribution to the firm, it is understood that the faculty member would offer his/her expertise to improve the design or suggest solution to a design. From the authors' experience, the "publish or perish" dilemma is not the only obstacle that prevents faculty members from gaining practical experience they can bring into the classroom. It is equally important that the firms hiring these faculty members understand their mission and provide appropriate engineering experience to them. Otherwise, the effectiveness of the engineering employment experience on improving classroom instruction 
will be limited. Clear communication between the firm and faculty member on the goals of the faculty member during their employment at the firm is paramount to the success.

\section{Bibliography}

1. Pomales-Garcia, C. and Liu, Y. (2007) "Excellence in Engineering Education: Views of Undergraduate Engineering Students", Journal of Engineering Education, ASEE, July, pp. 253-262.

2. "Real-World Experience Can Revitalize Teaching", Northwest Regional Educational Laboratory, http://www.nwrel.org/nwreport/dec98/article.html, retrieved 3/18/2009.

3. Uluatam, S. S. (1992) “Civil Engineering Experience and Education”, Journal of Professional Issues in Engineering Education and Practice, ASCE, Vol. 118, No. 1, January, pp. 71-76.

4. "Civil Engineering Overview", Sloan Career Cornerstone Center, www.careercornerstone.org, retrieved Feb. 3, 2009.

5. Akili, W. (2006) "Case Studies in Geotechnical/Foundation Engineering: Engaging Students and Bringing the Practice into the Classroom", Conference Proceedings of the 2006 ASEE Annual Conference and Exposition. June 18-21, Chicago, IL.

6. Hart, H. (2005) "Making the Process the Content: Connecting Engineering Students to the Real World", Proceedings of 2005 IEEE International Professional Communication Conference, article no. 1494209, pp. 447-450.

7. Rajiu, P.K. and Sankar, C.S. (1999) “Teaching Real-World Issues through Case Studies”, Journal of Engineering Education, ASEE, October, pp. 501-508.

8. Halpin, G., Halpin, G., Raju, P.K., Sankar, C.S., and Belliston, L. (2004) "Real-World Problems in the Classroom: Vital in Engineering Education", Proceedings of 2004 Frontiers in Education Conference, FIE 1, pp. T2F-13-T2F-18, October 20-23, Nashville, TN..

9. Eisenman, S. and List, G. (2003) "Hands on Experiences in Civil Engineering", Proceedings of 2003 ASEE Annual Conference, pp. 5827-5840, June 22-25, Nashville, TN.

10. Tullis, B.P. and Tullis, J.P. (2001) "Real-World Projects Reinforce Fundamentals in the Classroom", Journal of Hydraulic Engineering, 127(12), pp. 992-995.

11. Chou, K.C., Wilde, J.W., and Moaveni, S. (2005) "Integrating Major Design Experience throughout a Small Civil Engineering Program - a 2-Year Assessment and Implementation”, Chapter 17 of Innovation 2005 World Innovations in Engineering Education and Research, International Network for Engineering Education and Research (iNEER), March. (Invited submission)

12. Chou, K.C., Wilde, J.W., and Moaveni, S. (2007) "Subcontracting Senior Design Project in Civil Engineering", Journal of Professional Issues in Engineering Education and Practice, ASCE, Volume13, Issue 3, pp. 171-180, July.

13. Richter, D. and Loendorf, W. (2007) "Faculty with Industrial Experience Bring a Real World Perspective to Engineering", Proceedings of 2007 ASEE Annual Conference and Exposition, June 24-27, Honolulu, HI.

14. Dettman, M.A. (1999) "Professors as Practitioners: Is this Important to Students?", Proceedings of 1999 ASEE Annual Conference, pp. 4049-4054, June 20-23, Charlotte, NC.

15. Civil Engineering Body of Knowledge for the $21^{\text {st }}$ Century - Preparing the Civil Engineer for the future, $2^{\text {nd }}$ edition, ASCE, 2008

16. ASCE Policy 465: Academic Prerequisites For Licensure And Professional Practice, ASCE, April 24, 2007.

17. Manual of Steel Construction, $13^{\text {th }}$ Edition, AISC, 2005. 